\title{
Viral load and neuropathology in the SIV model
}

\author{
Delphine Boche ${ }^{\star, 1}$, Emmanuel Khatissian ${ }^{1}$, Françoise Gray $^{2}$, Pierre Falanga ${ }^{1}$, Luc Montagnier ${ }^{1}$ and \\ Bruno Hurtrel $^{1}$ \\ ${ }^{1}$ Unité d'Oncologie Virale, Institut Pasteur, 75724 Paris Cedex 15, France; ${ }^{2}$ Laboratoire d'Anatomie Pathologique, \\ Hôpital Raymond Poincaré, 92380 Garches, France
}

\begin{abstract}
To investigate neuropathological processes involved in HIV infection, a longitudinal analysis of central nervous system (CNS) changes was performed using the SIV-infected macaque model. Five animals were studied during the early phase and 13 during the asymptomatic and symptomatic phases. Histopathological analyses were performed on one cerebral fixed hemisphere whereas on the other frozen hemisphere in situ hybridisation, immunohistochemistry and RT - PCR were performed. Viral load was quantified by in situ hybridisation, CD4 and CD8 $\mathrm{T}$ cell infiltration by immunohistochemistry and mRNA cytokine expression (IL1 $\beta$, IL2, IL6, TNF $\alpha$, IFN $\gamma$ and TGF- $\beta$ 1) by semiquantitative RT-PCR. As reported for HIV-infected humans, the neuropathological analysis of SIV infected animals revealed four distinct lesion profiles: minimal changes, early encephalitis, leukoencephalopathy and encephalitis. No relationship was found between neuropathological findings, numbers of SIV replicating cells and T cell infiltration. CNS infection was found to be an early event characterised by glial activation, an increase in the level of IL1 $\beta$, TNF $\alpha$ and IL6 mRNA expression. During the asymptomatic and symptomatic phases, IL6 and IL1 $\beta$ mRNAs increase coincided with gliosis and the development of myelin lesions. The absence of relationship between neuropathological findings and viral load suggests that cerebral lesions are caused by an indirect mechanism. Inflammatory cytokine pattern associated with severe lesions show the key role of glial activation in the SIV neuropathological process.
\end{abstract}

Keywords: neuropathology; cytokines; lymphocyte T infiltration; SIV

\section{Introduction}

Neuropathology associated with HIV (human immunodeficiency virus) infection is one of the major complications of the AIDS (acquired immunodeficiency syndrome). The virological and cellular mechanisms by which HIV infection induces motor and cognitive disorders remain unknown (Chiodi et al, 1996; Dubois-Dalcq et al., 1990; Lazarini et al, 1997; Sharer, 1992; Spencer and Price, 1992). HIV neuropathogenesis is difficult to investigate because of the limited information provided by longitudinal analysis of cerebrospinal fluid (CSF) alterations and post-mortem studies.

Consequently, animal models are essential for studies of HIV neuropathology (Fox et al, 1997; Persidsky et al, 1995; Petry and Luke, 1997; Vitkovic et al, 1995; Zinc et al, 1998). SIV causes encephalopathy in the macaque similar to the neurological lesions in patients with AIDS and does

*Correspondence: D Boche

Received 28 August 1998; revised 10 November 1998; accepted 24 November 1998 so with comparable frequency (Chakrabarti et al, 1991; Ringler et al, 1988; Sasseville and Lackner, 1997; Sharer, 1994; Simon et al, 1992). In both HIVinfected human and SIV-infected macaque, the infection of the brain occurs early (Chakrabarti et al, 1991; Grant et al, 1987; Gray et al, 1992) and only monocyte-derived cells produce virus (Chakrabarti et al, 1991; Koenig et al, 1986; Lackner et al, 1991; Unger et al, 1992; Vazeux et al, 1987). It would be valuable to know whether a relatively small number of infected cells can cause severe neuropathology and whether this neuropathology is directly due to the virus itself or is induced by the host's response to infection. There is some in vitro evidence that microglial cells release various products which are toxic for brain cells, such as cytokines and neurotoxins. The AIDS dementia complex may result from the activity of one or more of these products (Benveniste, 1994; Gendelman et al, 1997; McEntee et al, 1992; Merrill and Martinez-Maza, 1993; Nottet et al, 1997; Persidsky et al, 1997; 
Vitkovic et al, 1994; Wilt et al, 1995). To determine whether the effects of the virus are direct or indirect, we conducted a longitudinal analysis of the CNS in SIV infected animals. We followed the development of neuropathology, the viral load, and the number of infiltrating T lymphocytes. Indeed, T lymphocytes have been reported to be present in the CNS of patients who died during either pre-AIDS or AIDS stages of the disease (Bell et al, 1993). Finally, we analysed cytokine expression to identify the cells involved in the neuropathological changes.

\section{Results}

\section{Acute infection}

Neuropathology and numbers of CNS infected cells Five animals were infected intravenously (i.v.) with the pathogenic isolate SIVmac 251 and sacrificed at 4, 7, and 14 days post-inoculation (p.i.). The neuropathological lesions (Table 1) were generally similar in the different regions examined although the median region displayed more severe lesions at each time point. In all animals, there were minimal changes, with astrogliosis, leptomeningeal and perivascular infiltrates, rare multinucleated giant cells (MGC), microglial nodules and white matter pallor. The severity of these lesions varied between the animals. The replicating SIV cells were enu-merated by in situ hybridisation (Figure 1). The virus was detected in all infected monkeys and was thus present in the brain as early as 4 days p.i. For this animal, the infected cells were only observed near blood vessels. Infected and productive cells were observed in all brain zones examined. The number of virus-replicating cells was low in all animals $\left(<\right.$ mean of five positive cells $\left./ 50 \mathrm{~mm}^{2}\right)$, and there was no obvious difference between the different time points. The density of infected cells was higher in the median zone than the other zones in all animals. They were found scattered throughout the brain, mostly in the white matter and fewer in the grey matter. Immunohistochemistry was used to reveal $\mathrm{CD}^{+}$and $\mathrm{CD}^{+} \mathrm{T}$ lymphocytes. These cells were found in all the zones studied in the CNS from the earliest time point ( 4 days), see Table 1 . There were more $\mathrm{CD}^{+}$cells than $\mathrm{CD} 4^{+}$cells. There was no detectable association between the number of infected cells, the count of $\mathrm{T}$ lymphocytes and neuropathology.

Cytokine production in the CNS To determine which cell type is involved in these pathological processes, semi-quantitative RT-PCR was used to assay cytokine mRNA (IL1 $\beta$, IL2, IL6, TNF $\alpha, \operatorname{IFN} \gamma$, and TGF- $\beta 1$ ) in the frontal and median area of the animals. During the early phase, the IL6 mRNA expressed transiently in the two animals sacrificed on day 7 p.i. (Figure 1). IL1 $\beta$ mRNA was constitutively produced, but was slightly more abundant on day 7 p.i. The level of TNF $\alpha$ mRNA was higher 7 days p.i. and TGF- $\beta 1$ mRNA was detected at a constant level throughout the early phase. Despite the presence of lymphocytes neither IL2 mRNA nor IFN $\gamma$ mRNA was detected in any animal sacrificed during the early phase.

\section{Asymptomatic and symptomatic phases}

Neuropathology and numbers of CNS infected cells Infected animals were sacrificed during the asymptomatic phase after predetermined periods of infection, or as soon as the first symptoms of the preAIDS stage appeared. The animals were classified according to length of infection before sacrifice and to neuropathological characteristics. The neuropathological analysis revealed various different patterns of lesions as reported for HIV-infected

Table 1 Neuropathology during the acute stage of SIV infection

\begin{tabular}{|c|c|c|c|c|c|c|c|c|c|c|c|c|c|c|c|}
\hline \multirow{2}{*}{$\begin{array}{l}\text { Neuropathology } \\
\text { Cerebral area }\end{array}$} & \multirow[b]{2}{*}{$F$} & \multirow[b]{2}{*}{$M$} & \multirow[b]{2}{*}{$C e$} & \multirow[b]{2}{*}{$F$} & \multirow[b]{2}{*}{$M$} & \multirow[b]{2}{*}{$\mathrm{Ce}$} & \multicolumn{3}{|c|}{ Minimal changes } & \multirow[b]{2}{*}{$F$} & \multirow[b]{2}{*}{$M$} & \multirow[b]{2}{*}{$C e$} & \multirow[b]{2}{*}{$F$} & \multirow[b]{2}{*}{$M$} & \multirow[b]{2}{*}{$\mathrm{Ce}$} \\
\hline & & & & & & & $F$ & $M$ & $\mathrm{Ce}$ & & & & & & \\
\hline Leptomenigeal infiltrates & \pm & \pm & - & \pm & - & - & - & - & - & + & + & + & ++ & + & - \\
\hline Perivascular infiltrates & - & - & - & - & - & - & - & - & - & - & - & - & - & \pm & - \\
\hline Multinucleated giant cell & - & - & - & - & - & - & - & + & - & - & - & - & \pm & $\overline{+}$ & \pm \\
\hline Microglial nodules & - & + & - & - & - & - & - & + & - & - & - & - & - & + & - \\
\hline Gliosis & + & + & \pm & + & + & \pm & \pm & \pm & - & ++ & ++ & ++ & + & + & + \\
\hline White matter pallor & - & - & - & - & - & - & - & - & - & \pm & \pm & \pm & - & - & - \\
\hline \multicolumn{16}{|l|}{$\begin{array}{l}\text { Infiltrating } \mathrm{T} \text { cells } \\
\text { (cerebral parenchyma) }\end{array}$} \\
\hline$-\mathrm{CD}^{+} / 50 \mathrm{~mm}^{2}$ & 1.1 & 0.9 & 1.5 & 1.6 & 0.5 & 1.2 & 1.3 & 1.2 & 5.9 & 1.7 & 0.8 & 0.8 & 0.6 & 0.8 & 1 \\
\hline$-\mathrm{CD}^{+} / 50 \mathrm{~mm}^{2}$ & 6.3 & 14.8 & 8.7 & 6.3 & 9.4 & 9.8 & 12 & 14.1 & 6.3 & 10.1 & 9.9 & 7.7 & 11 & 16.1 & 27.2 \\
\hline Days post inoculation & & 4 & & & 7 & & & 7 & & & 14 & & & 14 & \\
\hline
\end{tabular}

For each animal, the neuropathological analysis was performed in the frontal (F), median (M) area and the cerebellum (Ce). The frequency and severity of lesions are depicted as: leptomenigeal infiltrates, perivascular infiltrates, gliosis, white matter pallor: $( \pm)$ rare and moderate, $(+)$ frequent and moderate, $(++)$ frequent and marked; microglial nodule, multinucleated giant cell: $(+)<1<(++)<5$. Infiltration of $\mathrm{CD}^{+}$and $\mathrm{CD8}^{+} \mathrm{T}$ lymphocytes in cerebral parenchyma were quantified in the same area. The results are expressed as the mean by $50 \mathrm{~mm}^{2}$. 

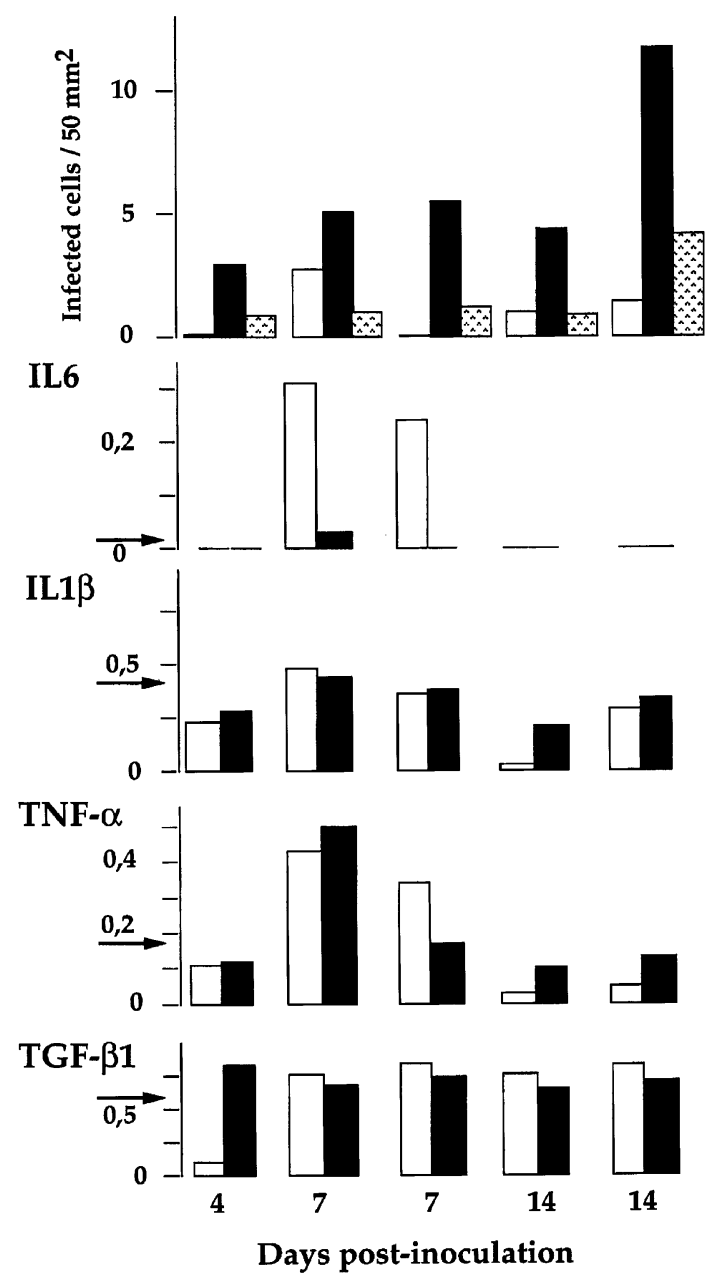

Figure 1 Quantification by in situ hybridisation of SIV infected cells and cytokine mRNA expression, in brains of monkeys inoculated i.v. with SIVmac 251 and sacrificed at 4, 7 and 14 days post-inoculation. SIV infected cells were counted on six or more complete sections performed in the frontal $(\square)$ and median ( ) area and the cerebellum (5; 8 ). The results are expressed as the mean by $50 \mathrm{~mm}^{2}$. Quantification by RT - PCR of mRNA cytokines (IL1 $\beta$, IL6, TNF $\alpha$, TGF- $\beta 1$ ) in the frontal ( $\square$ ) and median ( $)$ area of the same brains. The means of four non-infected animals are represented by arrows. IL2 and IFN $\gamma$ mRNA cytokines were also investigated but were not detected in all these brains.

humans: minimal changes, early encephalitis, leukoencephalopathy, and encephalitis. The neuropathology is described in Table 2 for animals presenting minimal changes and in Table 3 for animals presenting early encephalitis, leukoencephalopathy and encephalitis. The monkey sacrificed on day 30 had developed early encephalitis with microglial nodules in the frontal zone and myelin pallor in all zones examined. The animals with leukoencephalopathy presented marked white matter pallor, MGC, and leptomeningeal infiltrates. Encephalitis was manifest as numerous MGC, MGC nodules and substantial perivascular and leptome-

ningeal infiltrates. The replicating SIV cells were enumerated by in situ hybridisation (Figure 2). The distribution of SIV-infected cells was the same as during the early stage. The viral load did not appear to be related to the duration of infection, but was higher than during the early phase. There was no apparent relationship between the viral load in any of the three zones and the lesions observed. T lymphocytes, mostly $\mathrm{CD}^{+}$and fewer $\mathrm{CD}^{+}$, were present in the brains of all infected animals, but there was no relationship between the lesions, the viral load and $\mathrm{CD}^{+}$and $\mathrm{CD} 8^{+}$infiltration in animals presenting minimal changes (Table 2). The animal sacrificed on day 227 presented an encephalitis, a high viral load and the CD8 ${ }^{+}$count higher in the three areas tested (112 to 145 cells $/ 50 \mathrm{~mm}^{2}$ ). There was a large number of $\mathrm{T}$ lymphocytes in the median zone of the brain from the animal presenting early encephalitis (Table 3). The various haematological clinical markers assessed (T4/T8 ratio, antibody titers and antigenemia) did not associate with the brain viral load or the pattern of CNS lesions (Tables 2 and 3). Nevertheless the absence of antibodies and the presence of antigenemia were associated with the two encephalities.

Cytokine production in the CNS As described for early stages, mRNA cytokines were quantified by RT-PCR. The animals were classified according to length of infection before sacrifice and to neuropathological analysis. The findings are depicted in Figure 3. Animals presenting minimal changes had similar levels of IL1 $\beta$ and TGF- $\beta 1$ mRNAs but divergent levels of IL6 and TNF $\alpha$ mRNAs. However, there was no apparent relationship with the lesions observed. In both animals with leukoencephalopathy, IL1 $\beta$, IL6, and TGF- $\beta 1$ mRNAs were abundant, particularly in the frontal zone, despite a low level of TNF $\alpha$ mRNA. The animals suffering encephalitis had high levels of IL1 $\beta$, IL6, TNF $\alpha$ and TGF- $\beta 1$ mRNAs, although this overexpression was less pronounced in the animal sacrificed on day 227 p.i. The comparison between animals presenting severe neuropathology (encephalitis and leukoencephalopathy) and uninfected animals shows a significant difference $(P=0.05)$ for IL1 $\beta$ in the frontal area and IL6 in the frontal and median areas. As during the early phase, IL2 and IFN $\gamma$ mRNAs were not detected in any of the animals.

\section{Discussion}

The genesis of lesion during AIDS encephalopathy remains poorly understood. This is due to the paucity of human sample during the course of the disease. SIVmac 251 causes cerebral lesions in the CNS of rhesus macaque similar to those of HIVinfected human (Chakrabarti et al, 1991; Gray et al, 


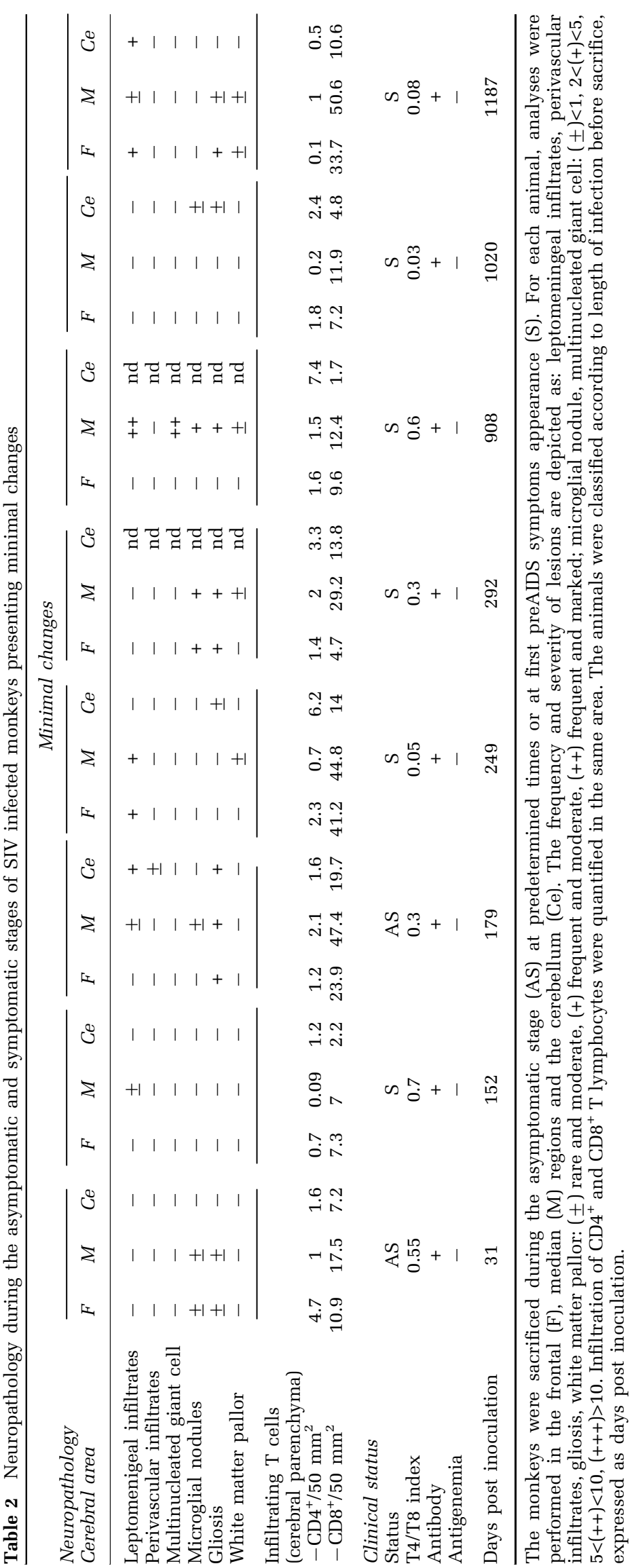


1996; Sharer, 1994). To understand the neuropathogenesis, we conducted a longitudinal analysis in this animal model. The relationship between viral load and CNS lesions was studied. Then to investigate the mechanisms involved, mRNA en- coding proinflammatory cytokines implicated in several CNS pathologies were quantified.

Throughout the early infection, the brain was constantly but not heavily infected. Despite the low numbers of virus replicating cells detected in the

Table 3 Neuropathology during the asymptomatic and symptomatic stages of SIV infected monkeys presenting early encephalitis (EE), leukoencephalopathy (L) or encephalitis (E)

\begin{tabular}{|c|c|c|c|c|c|c|c|c|c|c|c|c|c|c|c|}
\hline \multirow{2}{*}{$\begin{array}{l}\text { Neuropathology } \\
\text { Cerebral area }\end{array}$} & \multicolumn{3}{|c|}{$E E$} & \multicolumn{3}{|c|}{$L$} & \multicolumn{3}{|c|}{$L$} & \multicolumn{3}{|c|}{$E$} & \multicolumn{3}{|c|}{$E$} \\
\hline & $F$ & $M$ & Ce & $F$ & $M$ & $C e$ & $F$ & $M$ & $\mathrm{Ce}$ & $F$ & $M$ & $\mathrm{Ce}$ & $F$ & $M$ & $\mathrm{Ce}$ \\
\hline Leptomenigeal infiltrates & + & + & - & + & ++ & + & ++ & + & + & +++ & ++ & + & +++ & +++ & +++ \\
\hline Perivascular infiltrates & - & - & - & \pm & \pm & - & \pm & - & - & \pm & - & - & +++ & +++ & +++ \\
\hline Multinucleated giant cell & - & \pm & - & \pm & + & + & + & + & + & $\overline{++}$ & ++ & ++ & +++ & +++ & +++ \\
\hline Microglial nodules & - & + & + & + & - & \pm & + & \pm & - & + & - & - & +++ & +++ & +++ \\
\hline Gliosis & \pm & \pm & \pm & ++ & ++ & ++ & + & + & \pm & ++ & ++ & + & +++ & +++ & +++ \\
\hline White matter pallor & $\overline{+}$ & $\overline{+}$ & $\overline{+}$ & ++ & ++ & ++ & + & + & \pm & ++ & ++ & ++ & + & + & + \\
\hline \multicolumn{16}{|l|}{$\begin{array}{l}\text { Infiltrating T cells } \\
\text { (cerebral parenchyma) }\end{array}$} \\
\hline$-\mathrm{CD}^{+} / 50 \mathrm{~mm}^{2}$ & 0.5 & 1.3 & 3 & 0 & 0.1 & 0.1 & 0.4 & 0.4 & 0.3 & 1.7 & 0.7 & 3.4 & 0.3 & 0.2 & 2.3 \\
\hline$-\mathrm{CD}^{+} / 50 \mathrm{~mm}^{2}$ & 47.2 & 110.5 & 43.1 & 10.1 & 5.8 & 7.4 & 6.3 & 6.7 & 5.9 & 15.4 & 45.6 & 7 & 134.5 & 145.3 & 112.2 \\
\hline \multicolumn{16}{|l|}{ Clinical Status } \\
\hline Status & & AS & & & AS & & & AS & & & AS & & & $\mathrm{S}$ & \\
\hline T4/T8 index & & 0.66 & & & 0.3 & & & 0.3 & & & 1 & & & 0.3 & \\
\hline Antibody & & + & & & + & & & + & & & - & & & - & \\
\hline Antigenemia & & - & & & - & & & - & & & + & & & + & \\
\hline Days post inoculation & & 30 & & & 78 & & & 98 & & & 65 & & & 227 & \\
\hline
\end{tabular}

The legends of neuropathology and status are given in Table 2. The animals were classified according to neuropathological findings, early encephalitis (EE), leukoencephalopathy (L) and encephalitis (E) and length of infection before sacrifice, expressed as days post inoculation.

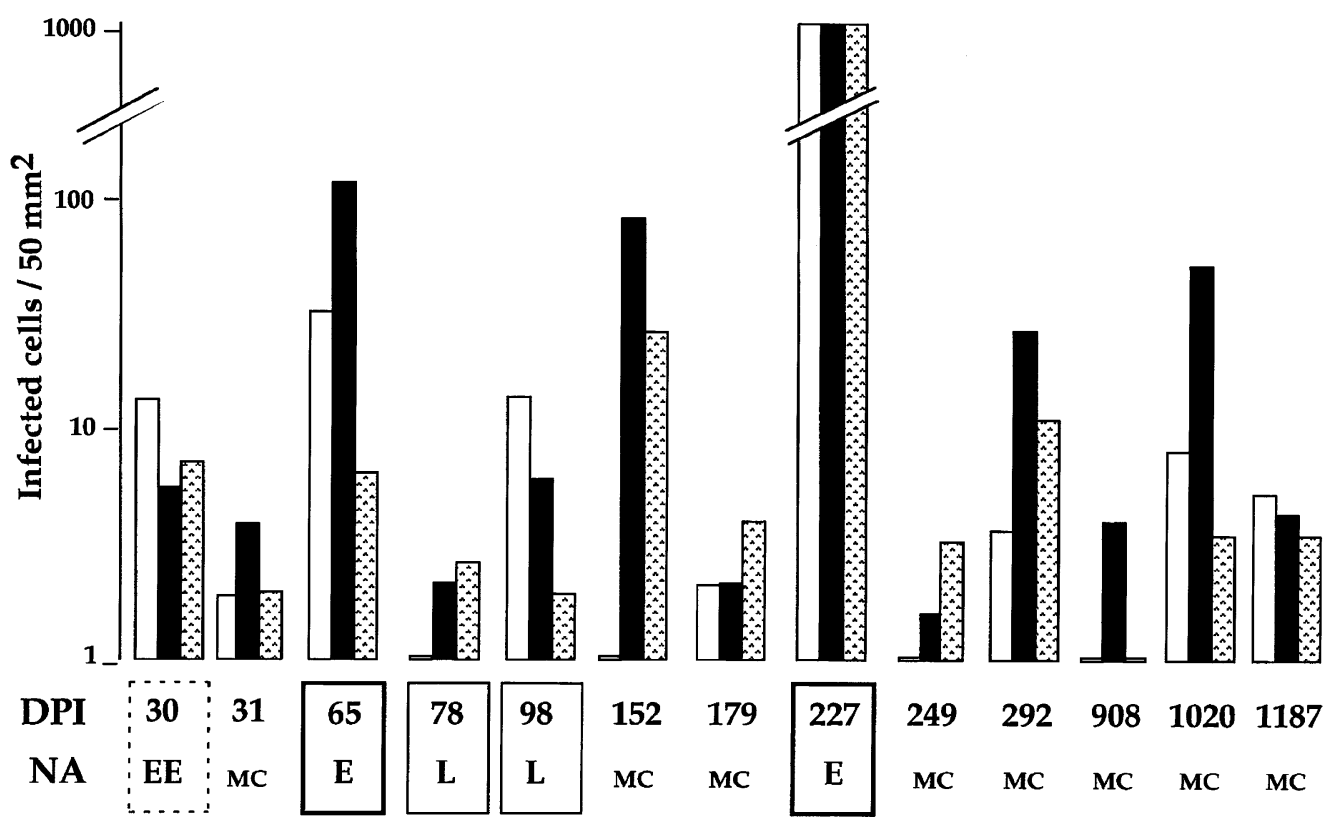

Figure 2 Productive infected cells in brain of SIV infected monkeys during the asymptomatic and symptomatic stages. The monkeys were sacrificed during the asymptomatic stage at predetermined times or at first preAIDS symptoms appearance. The animals were classified according to length of infection before sacrifice, expressed as days post inoculation (DPI), and to findings of neuropathological analysis (NA): minimal changes (MC), early encephalitis (EE), leukoencephalopathy (L) and encephalitis (E). The SIV infected cells were detected by in situ hybridisation and counted in the frontal $(\square)$ and median ( $\square$ ) area and the cerebellum (:5: $)$. The results are expressed as the mean by $50 \mathrm{~mm}^{2}$. 


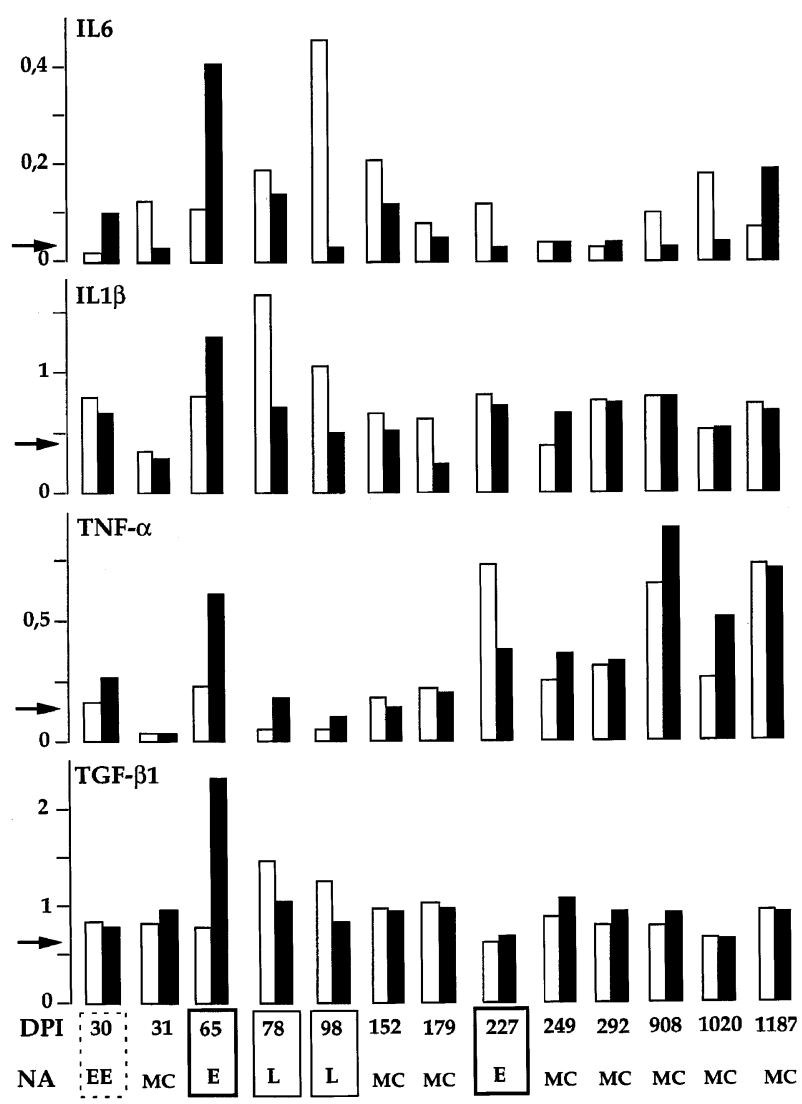

Figure 3 Quantification by RT - PCR of mRNA cytokines (IL1 $\beta$, IL6, TNF $\alpha$, TGF- $\beta 1$ ) in the frontal ( $\square$ ) and the median ( $\square$ ) area of the same brains that Figure 2. The animals were classified according to length of infection before sacrifice, expressed as days post inoculation (DPI), and to findings of neuropathological analysis (NA): minimal changes (MC), early encephalitis (EE), leukoencephalopathy (L) and encephalitis (E). The means of four non-infected animals are represented by arrows. IL2 and IFN $\gamma$ mRNA cytokines were also investigated but were not detected.

brain parenchyma, minimal changes, particularly leptomeninges infiltrates, microglial nodules, gliosis and white matter pallor could be visualised in the three areas studied. These results show that a low viral load can generate lesions more and less severe according to monkeys. These features observed in macaques infected by SIV are indistinguishable from those described for early HIVseropositive patients who died from non-natural causes in comparison with seronegative individuals (Gray et al, 1992, 1996; Bell et al, 1993). Both CD4 ${ }^{+}$ and $\mathrm{CD}^{+} \mathrm{T}$ lymphocyte infiltration was observed in all infected animals, but the $\mathrm{CD}^{+}$cell count was much higher than the CD4 ${ }^{+}$cell count. There was no relationship between the viral load, the neuropathology and the $\mathrm{T}$ lymphocyte count. The amounts of the proinflammatory cytokine (IL1 $\beta$, IL6 and TNF $\alpha$ ) mRNAs were high 7 days p.i. and this was associated with the appearance of infected cells in the CNS and a diffuse astrocyte and microglia gliosis. As the major source of $\mathrm{TNF} \alpha$ is activated macrophages, the production of $\mathrm{TNF} \alpha 7$ days p.i. reflects mainly the transition from monocytes to activated macrophages in the CNS. Our in vivo data and that of others corroborate the involvement of monocytes/macrophages in the early CNS infection (Chakrabarti et al, 1991; Lane et al, 1996; Zhu et al., 1995). The IL1 $\beta$ and IL6 production may be a consequence of macrophage infiltration or reflect glial cell activation. These two cytokines are both synthesised by macrophages, astrocytes and microglial cells (Morganti-Kossmann et al, 1992; Woodroofe, 1995).

As noted above for the early phase, during the asymptomatic and symptomatic stage, there was no relationship between the neuropathology, the viral load and the $\mathrm{CD8}^{+} \mathrm{T}$ lymphocyte count. The dissociation between the low viral load and the severity of the lesions was clear in animals presenting leukoencephalopathy. Nevertheless for the encephalitis case sacrificed at 227 days p.i., the severe neuropathology was associated with a high viral load and numerous CD8 ${ }^{+}$T cells. High IL1 $\beta$, IL6 and TGF- $\beta 1$ mRNA levels were associated with severe lesions. The role of TGF- $\beta 1$ is unclear. We do not know whether it has beneficial or detrimental effects on the brain. The increased level could be a consequence of the terminal phase rather than a cause of the severe lesions of the AIDS phase (Morganti-Kossmann et al, 1992; Wyss-Coray et al, 1997). The myelin lesions were always associated with IL1 $\beta$ and IL6 production, nevertheless some animals presented a small increase without myelin lesions. This dissociation between the virus replicate cells, the cerebral lesions and cytokine expression indicates that there is individual variability in susceptibility to the virus. During the primary phase, the IL1 $\beta$ mRNA level and IL6 mRNA production were associated with microglia and astrocyte activation. This activation was visualised as gliosis without any severe lesion. The relationship with myelin lesions appeared only during the asymptomatic and symptomatic phases. These observations suggest that prolonged and constant activation of microglia and astrocytes is necessary for the development of myelin lesions. In transgenic mice, overproducing IL6 in astrocytes, the microglia was activated with a pattern that is suggestive of a major contribution of IL6 to the development of these lesions (Campbell et al, 1993; Gold et al, 1996). It must be noted that in the two animals developing encephalitis both had antigenemia, lack of antibodies and high viral load in the brain. As previously described, there is an association between the development of encephalitis and rapid disease progression (Westmoreland et al, 1998).

mRNA for IL2 and IFN $\gamma$ cytokines, both produced by $\mathrm{T}$ lymphocytes, were not detected in the brains of any of the animals examined. Furthermore, the absence of relationship between the lymphocyte 
counts and the pattern of lesions argues against a role for lymphocytes for the development of the lesions. The contribution of these cells to the infection process, either neuroinvasion or progression of the disease, is unknown. The non-detection of these two cytokines could be due to the local environment of the CNS that exerting a complex negative-regulatory effect on brain recruited T cells, as shown in the Sindbis virus encephalitis model (Irani et al, 1997). However, T cells are a minority cell type in the CNS, and the failure to detect IFN $\gamma$ mRNA may have been due to the detection threshold of the technique used. Thus we can not totally exclude the possibility that $\mathrm{T}$ lymphocytes contribute to the neuropathological changes, as suggested by Merrill (Merrill and Martinez-Maza, 1993) and An (An et al, 1996).

In conclusion, our longitudinal study of SIVinfected macaques shows that the virus penetrates into the CNS via the macrophage early during the infection. The early events were characterised by glial activation, an increase in the level of IL1 $\beta$ mRNA and local production of IL6 mRNA. The absence of relationships between the lesions observed and the number of infected cells confirms the hypothesis in favour of cerebral damages mediated by indirect mechanism in SIV and HIV infections. The association between severe lesions and IL1 $\beta$ and IL6 levels, cytokines produced mainly by glial cells, suggests that these lesions were generated in susceptible animals presenting a persistent glial activation in response to SIV production.

\section{Materials and methods}

\section{Animals and SIV infection}

Prior to inoculation, adult rhesus monkeys (Macaca mulatta) were demonstrated to be seronegative for STLV-1, SRV-1 (type D retrovirus), herpes B virus, and SIVmac. Animals were infected with the pathogenic SIVmac 251 isolate provided by $\mathrm{R}$ Desrosiers (New England Regional Primate Research Center, Southborough, MA, USA) (Daniel et al, 1985). Monkeys were infected by intravenous (i.v.) injection of $3 \times 10^{3}$ (TCID), tissue culture infectious doses and killed at various times postinoculation (p.i.), from 4 days p.i. to the terminal stage of infection. Four uninfected animals were used as negative controls.

\section{Serologic assays}

Antigenemia was detected by measurement of SIV p27 gag antigen in monkey sera, using a SIVmac antigen capture ELISA test (Coulter). The antibody response to SIV was monitored with an HIV-2 ELISA test that contain viral antigens mix. The result is positive if the difference between densitometry with antigen and densitometry without antigen is higher than 0.3 (Elavia-II, SanofiPasteur).

\section{Histopathology}

Complete necropsy and histopathological examinations were performed, and a systematic study was carried out on the brain. For each animal, one cerebral hemisphere, half of the cerebellum and half of the brainstem were fixed in formalin, embedded in paraffin and celloidin. Sections were stained by haematoxylin and eosin, Loyez stain for myelin and Bodian silver impregnation combined with Luxol fast blue. Myelin pallor was judged on celloidin embedded sections. Histopathological analysis was performed on seven different brain sections: between A35 and A25 for the frontal area, between A15 and A5 for the median area (basal ganglia, thalamus, ventral nucleus) and the cerebellum (Szabo and Cowan, 1983). Findings in infected monkeys were compared with those in uninfected animals. The animals were classified according to the human pattern. Minimal changes include essentially gliosis, leptomeningeal infiltrates and microglial nodules. HIV leukoencephalopathy is defined as a diffuse damage to the white matter including myelin loss, reactive astrocytosis, macrophages and MGC. HIV encephalitis is defined by multiple disseminated foci composed of microglia, macrophages and MGC; these lesions may include reactive gliosis, lymphocytic infiltrates and myelin loss. Early encephalitis is less severe and occurs during the early stage of infection.

Quantification of virus load by in situ hybridisation In situ hybridisation was performed on the other half sample, cooled in liquid nitrogen and stored at $-80^{\circ} \mathrm{C}$. Hybridisation was performed as previously described (Chakrabarti et al, 1991) with RNA probes derived from a fragment of the SIVmac-142 plasmid clone (Chakrabarti et al, 1987) inserted into the 'Bluescript' vector (Vector Cloning System). An RNA antisense probe nef was generated from the $\mathrm{T} 7$ promoter by in vitro transcription. The same hybridisation technique was used for positive controls (SIV-infected cultured cells spotted onto slides coated with 3-aminopropyltriethoxysilane (Sigma)), and negative controls (brain tissue from uninfected animals). Infected cells were counted on a minimum 18 complete sections and the sum was divided by the entire surface analysed. The results expressed as a mean values per $50 \mathrm{~mm}^{2}$. The sections were from the same area investigated histopathologically.

Quantification of $T$ cells by immunohistochemistry Frozen tissue sections cut on a cryostat were investigated by immunohistochemistry techniques. Leu2a (anti-CD8, Becton Dickinson), OKT4 (antiCD4, Ortho-Diagnostic), Kim7 (anti-CD68, Behring) antibodies were used to detect $\mathrm{T}$ lymphocytes. CD8 and CD4 T cells were respectively characterised as $\mathrm{CD}^{+}$and $\mathrm{CD}^{+}{ }^{+} \mathrm{CD}^{-} 8^{-} \mathrm{T}$ cells. Stained cells were counted in infected brains and compared to those in 
brains from uninfected animals (CD4 ${ }^{+}$cells $<0.42$ cells for $50 \mathrm{~mm}^{2}, \mathrm{CD8}^{+}$cells $<1.67$ cells for $50 \mathrm{~mm}^{2}$ ).

\section{Quantification of cytokine mRNA expression by} semiquantitative $R T-P C R$

Total RNA was extracted from brain tissues after lysed in RNAzol (Bioprobe, France). RNA was quantified by measuring the optical density at 260 and $280 \mathrm{~nm}$. cDNA was synthesised from oligodT(16)-primed RNA by incubation with M-MLV RT 'SuperScript' (Gibco BRL) and dNTPs (Pharmacia). Each cDNA sample was subjected to PCR amplification with cytokine gene-specific primers: (interleukin (IL)-1 $\beta$, IL2, IL6, Interferon (IFN)- $\gamma$, Tumor Necrosis Factor (TNF)- $\alpha$ (Villinger et al (1993), and Transforming Growth Factor (TGF)- $\beta 1$ (Clontech).

\section{References}

An SF, Ciardi A, Giometto B, Scaravilli T, Gray F, Scaravilli F (1996). Investigation on the expression of major histocompatibility complex class II and cytokines and detection of HIV-1 DNA within brains of asymptomatic and symptomatic HIV-1-positive patients. Acta Neuropathol (Berl) 91: 494-503.

Bell JE, Busuttil A, Ironside JW, Rebus S, Donaldson YK, Simmonds P, Peutherer JF (1993). Human immunodeficiency virus and the brain: investigation of virus load and neuropathologic changes in pre-AIDS subjects. J Infect Dis 168: 818-824.

Benveniste EN (1994). Cytokine circuits in Brain: Implications for AIDS dementia complex. In: HIV, AIDS, and the Brain. Price RW and Perry, SW (eds). Raven Press: New York, pp 71-78.

Campbell IL, Abraham CR, Masliah E, Kemper P, Inglis JD, Oldstone MB, Mucke L (1993). Neurologic disease induced in transgenic mice by cerebral overexpression of interleukin 6. Proc Natl Acad Sci USA 90: 1006110065.

Chakrabarti L, Guyader M, Alizon M, Daniel MD, Desrosiers RC, Tiollais P, Sonigo P (1987). Sequence from simian immunodeficiency virus from macaque and its relationship to other human and simian retroviruses. Nature 328: 543-547.

Chakrabarti L, Hurtrel M, Maire MA, Vazeux R, Dormont D, Montagnier L, Hurtrel B (1991). Early viral replication in the brain of SIV-infected rhesus monkeys. Am J Pathol 139: 1273-1280.

Chiodi F, Britton S, Elovaara I (1996). Conference summary: Pathogenic mechanisms of HIV type 1associated neurological symptoms. AIDS Res Hum Retrov 12: $1191-1194$.

Daniel MD, Letvin NL, King NW, Kannagi M, Sehgal PK, Hunt RD, Kanki PJ, Essex M, Desrosiers RC (1985). Isolation of a T-cell tropic HTLV-III like retrovirus from macaques. Science, 228: 1201-1204.

Dubois-Dalcq ME, Jordan CA, Kelly WB, Watkins BA (1990). Understanding HIV-1 infection of the brain: a challenge for neurobiologists. AIDS 4: 567-576.

Fox HS, Gold LH, Henriksen SJ, Bloom FE (1997). Simian immunodeficiency virus: A model for neuroAIDS. Neurobiol Dis 4: 265-274.
PCR products were analysed on $1.8 \%$ agarose gels. The amount of DNA in each band was determined by densitometry (number of pixels), using Optilab ${ }^{\mathrm{TM}}$ / Pro 2.5 (Graftek, Mirmande-France) and normalised for the amount of mRNA encoding glyceraldehyde3-phosphate dehydrogenase (GADPH), detected in the sample. The amount of cDNA and thus cytokine mRNA is reported as the cytokine mRNA/GADPH mRNA ratio.

\section{Acknowledgement}

This work was supported by 'l'ANRS', by the Concerted Action from European Communities and 'la CANAM'.

Gendelman HE, Persidsky Y, Ghorpade A, Limoges J, Stins M, Fiala M, Morrisett R (1997). The neuropathogenesis of the AIDS dementia complex. AIDS 11: S $35-\mathrm{S} 45$

Gold LH, Heyser CJ, Roberts AJ, Henriksen SJ, Steffensen SC, Siggins GR, Bellinger FP, Chiang CS, Powell HC, Masliah E, Campbell IL (1996). Behavioral and neurophysiological effects of CNS expression of cytokines in transgenic mice. Adv Exp Med Biol 402: $199-205$.

Grant I, Atkinson JH, Hesselink JR, Kennedy CJ, Richman DD, Spector SA, McCutchan JA (1987). Evidence for early central nervous system involvement in the acquired immunodeficiency syndrome (AIDS) and other human immunodeficiency virus (HIV) infections. Studies with neuropsychologic testing and magnetic resonance imaging [published erratum appears in Ann Intern Med 1988 Mar; 108(3):496]. Ann Intern Med 107: 828-836.

Gray F, Lescs MC, Kehoane C, Paraire F, Marc B, Durigon M, Gherardi R (1992). Early brain changes in HIV infection: neuropathological study of 11 HIV seropositive, non-AIDS cases. J Neuropathol Exp Neurol 51: 177-185.

Gray F, Scaravilli F, Everall I, Chretien F, An S, Boche $\mathrm{D}$, Adle-Biassette $\mathrm{H}$, Wingertsmann L, Durigon M, Hurtrel B, Chiodi F, Bell J, Lantos P (1996). Neuropathology of early HIV-1 infection. Brain Pathol 6: $1-15$.

Irani DN, Lin KI, Griffin DE (1997). Regulation of brainderived $\mathrm{T}$ cells during acute central nervous system inflammation. I Immunol 158: 2318-2326.

Koenig S, Gendelman HE, Orenstein JM, Dal Canto MC, Pezeshkpour GH, Yungbluth M, Janotta F, Aksamit A, Martin MA, Fauci AS (1986). Detection of AIDS virus in macrophages in brain tissue from AIDS patients with encephalopathy. Science 233: 1089-1093.

Lackner AA, Smith MO, Munn RJ, Martfeld DJ, Gardner MB, Marx PA, Dandekar S (1991). Localization of simian immunodeficiency virus in the central nervous system of rhesus monkeys. Am J Pathol 139: 609621. 
Lane JH, Sasseville VG, Smith MO, Vogel P, Pauley DR, Heyes MP, Lackner AA (1996). Neuroinvasion by simian immunodeficiency virus coincides with increased numbers of perivascular macrophages/microglia and intrathecal immune activation. J Neurovirol 2: $423-432$.

Lazarini F, Seihlean D, Rosenblum O, Suarez S, Conquy L, Uchihara T, Sazdovitch V, Mokhtari Ki, Maisonobe T, Boussin F, Katlama C, Bricaire F, Duyckaerts C, Hauw JJ (1997). Human immunodeficiency virus type 1 DNA and RNA load in brains of demented and nondemented patients with acquired immunodeficiency syndrome. J Neurovirol 3: 229-303.

McEntee MF, Gorrell MD, Adams RJ, Narayan O, Pitha P (1992). Tumor necrosis factor and interleukin 6 production during interaction between activated CD4+ lymphocytes and simian immunodeficiency virus-infected macrophages. J Gen Virol 73: 11071116.

Merrill JE, Martinez-Maza O (1993). Cytokines in AIDSassociated nervous and immune system dysfunction. Methods in Neurosciences 17: 243-266.

Morganti-Kossmann MC, Kossmann T, Wahl SM (1992). Cytokines and neuropathology. TiPS 13: 286-291.

Nottet HSLM, Bar DR, Vanhassel H, Verhoef J, Boven LA (1997). Cellular aspects of HIV-1 infection of macrophages leading to neuronal dysfunction in vitro models for HIV-1 encephalitis. J Leukoc Biol 62: $107-116$.

Persidsky NC, Nottet HSLM, Sasseville VG, Epstein LG, Gendelman HE (1995). The development of animal model system for HIV-1 encephalitis and its associated dementia. J Neurovirol 1: 229-243.

Persidsky Y, Buttini M, Limoges J, Bock P, Gendelman HE (1997). An analysis of HIV-1-associated inflammatory products in brain tissue of humans and SCID mice with HIV-1 encephalitis. J Neurovirol 3: 401416.

Petry H, Luke W (1997). Infection of macaque monkeys with simian immunodeficiency virus - An animal model for neuro-AIDS. Intervirology 40: 112-121.

Ringler DJ, Hunt RD, Desrosiers RC, Daniel MD, Chalifoux LV (1988). Simian immunodeficiency virus-induced meningoencephalitis: natural history and retrospective study. Ann Neurol 23: 101-107.

Sasseville VG, Lackner AA (1997). Neuropathogenesis of simian immunodeficiency virus infection in macaque monkeys. I Neurovirol 3: 1-9.

Sharer LR (1992). Pathology of HIV-1 infection of the central nervous system. A review. J Neuropathol Exp Neurol 51: 3-11.

Sharer LR (1994). Neuropathology and pathogenesis of SIV infection of the central nervous system. In: HIV, AIDS and the brain. Price RW and Perry SW, (eds). Raven Press: New York, pp 133-145.
Simon MA, Chalifoux LV, Ringler DJ (1992). Pathologic features of SIV-induced disease and the association of macrophage infection with disease evolution. AIDS Res Hum Retrov 8: $327-337$.

Spencer DC, Price RW (1992). Human immunodeficiency virus and the central nervous system. Annu Rev Microbiol 46: 655-693.

Szabo J, Cowan WM (1983). A stereotaxic atlas of the brain of the cynomolgus monkey (Macaca fascicularis). J Compar Neurol 222: 265-300.

Unger RE, Marthas ML, Lackner AA, Pratt-Lowe E, Lohman BL, Van Rompay K, Luciw PA (1992). Detection of simian immunodeficiency virus DNA in macrophages from infected rhesus macaques. J Med Primatol 21: $74-81$.

Vazeux R, Brousse N, Jarry A, Henin D, Marche C, Vedrenne C, Mikol J, Wolff M, Michon C, Rozenbaum W (1987). AIDS subacute encephalitis. Identification of HIV-infected cells. Am J Pathol 126: 403-410.

Villinger F, Hunt D, Mayne A, Vuchetich M, Findley H, Ansari AA (1993). Qualitative and quantitative studies of cytokines synthesized and secreted by non-human primate peripheral blood mononuclear cells. Cytokine 5: $469-479$.

Vitkovic L, da Cunha A, Tyor WR (1994). Cytokine expression and pathogenesis in AIDS brain. In: HIV, AIDS and the brain. Price RW and Perry SW, (eds). Raven Press: New York, pp 203-222.

Vitkovic L, Stover E, Koslow SH (1995). Animals models recapitulate aspects of HIV/CNS disease. AIDS Res Hum Retrov 11: $753-759$.

Westmoreland SV, Halpern E, Lackner AA (1998). Simian immunodeficiency virus encephalitis in rhesus macaques is associatd with rapid disease progression. I Neurovirol 4: 260-268.

Wilt S, Milward E, Zhou JM, Nagasato K, Patton H, Rusten R, Griffin DE, O’Connor M, Dubois-Dalcq M (1995). In vitro evidence for a dual role of tumor necrosis factor- $\alpha$ in human immunodeficiency virus type 1 encephalopathy. Ann Neurol 37: 381-394.

Woodroofe MN (1995). Cytokine production in the central nervous system. Neurology 45: S6-S10.

Wyss-Coray T, Borrow P, Brooker MJ, Mucke L (1997). Astroglial overproduction of TGF- $\beta 1$ enhances inflammatory central nervous system disease in transgenic mouse. J Neuroimmunol 77: 45-50.

Zhu GW, Liu ZQ, Joag SV, Pinson DM, Adany I, Narayan O, McClure HM, Stephens EB (1995). Pathogenesis of lymphocyte-tropic and macrophage-tropic SIVmac infection in the brain. I Neurovirol 1: 78-91.

Zinc MC, Spelman JP, Bedno-Robinson R, Clements JE (1998). SIV infection of macaques - Modeling the progression to AIDS dementia. J Neurovirol 4: 249259. 